\title{
Does Individual's Income always Matter Happiness?: Evidence from China
}

\author{
${ }^{1}$ Yugang HE, ${ }^{2}$ Renhong WU \\ 1. First Author Doctoral Student, Department of International Trade, Jeonbuk National University, \\ South Korea, Email: 1293647581@jbnu.ac.kr \\ 2. Corresponding Author Doctoral Student, Department of International Trade, Jeonbuk National \\ University, South Korea, Email:wurenhongbini@163.com
}

Received: November 06, 2019 Revised: November 30, 2019 Accepted: March 05, 2020

\begin{abstract}
As people's income rises dramatically, people's happiness seems not as high as expected. In fact, there are two different arguments about the relationship between income level and happiness. The focus of the debate is whether the correlation between income and probability of happiness is positive or negative. Therefore, we hypothesizes that the relationship between income and probability of happiness presents an inverted U-shaped curve. Then, this paper sets China as an example to explore the effect of income on happiness. The data from the Chinese General Social Survey (CGSS) in 2015 is employed to conduct empirical analyses under the Probit model and the Zero-Inflation-Passion model. The empirical findings indicate that the effect of income on happiness presents an inverted U-shaped curve and significantly in statistic. Meanwhile, spouse's income, educational level, marriage time and house property have a positive and significant effect on happiness. Conversely, age and local living standards have a negative and significant effect on happiness. Unfortunately, even though registered residence and children have a negative effect on happiness, they do not get through the significant test. In order to ensure the robustness of our empirical results, we test the robustness of the above empirical results by adjusting the sample size. The results of robustness test verify that our empirical results are robust. Moreover, this paper also makes a small contribution to the current literature with a sample from China.
\end{abstract}

Keywords: Income, Happiness, Probit Model, Zero-Inflation-Passion Model, Inverted U-shaped Curve

JEL Classification Code: C21, M50, P36

\section{Introduction}

Happiness refers to a series of joyful and pleasant emotions produced subjectively by human beings based on their own sense of satisfaction and security. As a part of the psychosocial system, happiness is influenced by many complex factors. These factors include the economic factors such as employment status and income level, social factors such as education level and marital quality, demographic factors such as gender and age, cultural factors such as values and traditional habits, psychological factors such as national character, self-esteem, attitude towards life, personality characteristics and achievement motivation, political factors such as democratic rights benefits and opportunities for participation. In this paper, in terms of the economic factors, we mainly focus on the effect on income on happiness. As a matter of fact, what is the relationship between income and happiness? This question is a topic that economists have been exploring for a long time, but it is always difficult to get a unified answer. To be sure, everyone wants to 
be happy. The pursuit of happiness is also the goal of everyone's life. Strangely, however, economists have avoided talking about happiness for quite a long time. Why is that? From a methodological point of view, most economists believe that happiness is immeasurable, incalculable and unscientific. They apply the concept of utility instead of happiness to microeconomic theory, explaining people's choices between different objects in terms of utility (the theory of explicit preference). Economists take it for granted that the higher income enables people to choose between more goods and services. That is, the higher income means higher level of happiness. As a result, almost all economics textbooks give only a simple theorem that the utility increases with income. The growth of income makes people able to buy more goods and enjoy better service, which improves people's personal utility and ultimately affects the happiness of individuals and families. However, it has been proved that with the increasing income, people's happiness has not been synchronized and balanced growth, which is the famous Easterlin paradox. For example, Caporale, Georgellis, Tsitsianis and Yin (2009) use the cross-sectional data of 19 European countries from the first two rounds of European Social Survey to analyze the relationship between income and happiness. They find that there is indeed a positive, statistically significant relationship between income and happiness. Bartram (2011) obtains the same conclusion with a sample from United States. Both results of Caporale, Georgellis, Tsitsianis and Yin (2009) and Bartram (2011) support the Easterlin paradox. However, Kenny (1999) employ the time series evidence from happiness surveys in 10 rich countries to conduct empirical analyses. He finds no causal relationship supporting growth to happiness. Binswanger (2006) also finds the same results. Moreover, Bruni and Stanca (2006) find that the effect of income on happiness is negative. Their results support the Easterlin paradox.

In this paper, we set China as an example to explore the effect of income on happiness. Based previous researches' achievements, the findings indicate that there three categories about the effect of income on happiness. The first is that the effect of income on happiness is positive; the second is that the effect of income on happiness is negative; the third is that the effect of income on happiness is not significant. Therefore, we hypothesize that the effect of income on happiness presents an inverted U-shaped curve. Then, using the data from the Chinese General Social Survey (CGSS) in 2015 to conduct empirical analyses under the Probit model and the Zero-Inflation-Passion model, the empirical findings indicate that the hypothesis is supported. Said differently, the effect of income on happiness presents an inverted U-shaped curve. Meanwhile, the empirical findings also show that spouse's income, educational level, marriage time and house property have a positive and significant effect on happiness.Conversely, age and local living standards have a negative and significant effect on happiness. Unfortunately, even though registered residence and children have a negative effect on happiness, they do not get through the significant test. Furthermore, to ensure the reliability and accuracy of the above empirical results, The full sample which cover the whole of China is divided into three sub-samples (eastern region, central region and western region) to re-estimate the the effect of income on happiness, respectively. The result of robustness test indicate that our conclusions are robust.

To this end, the rest of this paper proceeds as follows. Section two lays out the literature review and hypothesis. Section three presents variables and model. Section four provides the empirical results. Section five offers the conclusion. All tables are in the appendix.

Table 1: Variable Description

\begin{tabular}{|c|c|c|c|c|}
\hline $\begin{array}{c}\text { Variable } \\
\text { Type }\end{array}$ & Abbreviation & Full Name & Definition & Source \\
\hline $\begin{array}{c}\text { Dependent } \\
\text { Variable }\end{array}$ & $H$ & Happiness & $\begin{array}{c}\text { If a respondent feels happy, H equals } \\
\text { one. Otherwise, zero }\end{array}$ & CGSS \\
\hline \multirow{2}{*}{$\begin{array}{c}\text { Independent } \\
\text { Variable }\end{array}$} & $I$ & Income & $\begin{array}{c}\text { Logarithmic value of respondent's } \\
\text { annual income }\end{array}$ & CGSS \\
\cline { 2 - 5 } & $I^{2}$ & Square of income & $\begin{array}{c}\text { Square of logarithmic value of } \\
\text { respondent's annual income }\end{array}$ & CGSS \\
\hline $\begin{array}{c}\text { Control } \\
\text { Variable }\end{array}$ & $R R$ & Registered residence & $\begin{array}{c}\text { If a respondent belongs to rural } \\
\text { registration, RR equals one. Otherwise, } \\
\text { zero }\end{array}$ & CGSS \\
\hline
\end{tabular}




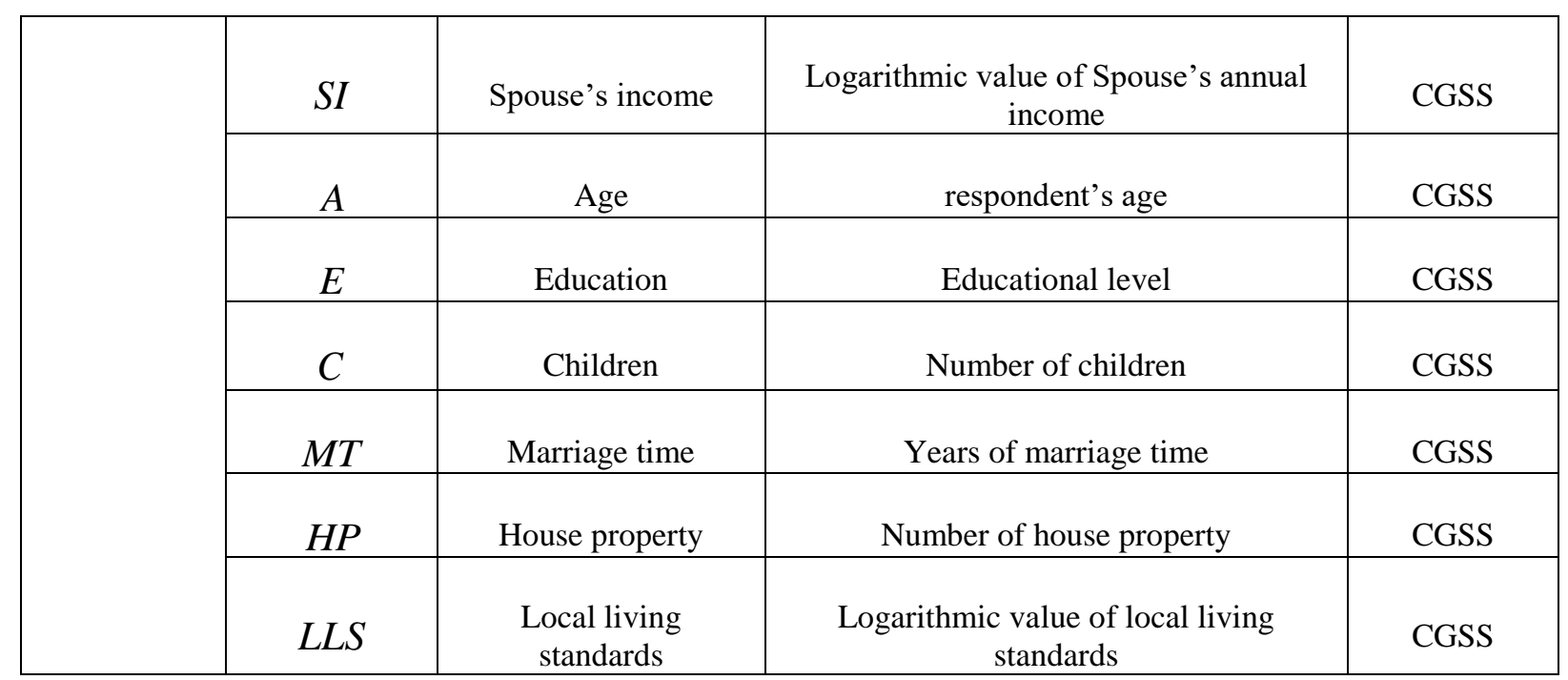

Note: CGSS represents the Chinese General Social Survey in 2015.

\section{Literature review and Hypothesis}

Over the past two decades, with the rapid development of the global economy, people's happiness level has begun to receive great attention after material satisfaction. Therefore, in recent years, economic research on happiness has developed rapidly. Stutzer (2004) presents empirical evidence on the impact of income aspiration on personal wellbeing based on a new, more direct and more general way. Via empirical analyses, he finds that people's satisfaction with life is reduced by high income aspirations. Therefore, the increase of aspiration level in the negative impact on well-being is relatively the same as that the positive impact of equal income growth on well-being is similar to the absolute amount. This indicates that the subjective well-being depends only on the gap between income aspirations and actual income, not on income level. Ball and Chernova (2008) try to explore the determinants of happiness in terms of absolute income, relative income or expected income. They use the data from Taiwan Social Change Survey over the period 1999 to 2002 to conduct empirical analyses under the ordered probit model. They find that when the absolute income increases, people who live in Taiwan will feel happier. But, this kind of marginal effect will be reducing. Moreover, they also find that the happiness of people who live in Taiwan is not only determined by the absolute income, but also closely related with the relative income and expected income. Knabe and Rätzel (2010) find that the income is an important factor that affects individual's happiness. Knabe and Rätzel (2010) use the German Socio-Economic Panel for the period from 1999 to 2006. Their sample includes all couples with an age range from 18 to 65 . Those couples are treated as a group who is active in the labour force. Employing an unbalanced panel with about 17000 observations to explore that the effect of income on happiness is downward biased (the reason is that higher income needs more work effort). They find that there is no evidence of underestimation. The reason is that the effect of working hours on happiness is very hill-shaped and small. Powdthavee (2010) attempts to discuss the issue that psychologists consider that income has little effect on life satisfaction (or happiness). However, the problem of income endogeneity in the equation of life satisfaction has rarely been solved. They try to estimate the causal effect of income on happiness. By instrumentalizing income and taking into account unobserved heterogeneity, these problems result in an estimated income effect that is almost twice the estimated value in the basic norms. The findings call for a reassessment of previous studies, which show that money can not buy happiness.

Becchetti, Trovato and Londono Bedoya (2011) collect more than 100,000 representatives from 82 countries to analyze the issue that the time spent on interpersonal relationships has a significant and positive impact on happiness. Through related analyses, they find that individual's income has a negative effect on happiness. Oshio, Nozaki and Kobayashi (2011) attempts to compare three major Asian countries (China, Japan and Korea) with the United States, and to analyze the impact of relative income on happiness on the basis of national surveys in these countries. They find that consistent with previous studies in Western countries, the comparison of personal income and average income with the reference group is significantly correlated with personal happiness in Asia. Meanwhile, in China, the 
relationship between personal income and happiness is closer than that of family income, whereas in Japan and Korea, the opposite is true. Paul and Guilbert (2013) set Australia as an example to explore the Easterlin Paradox (incomehappiness puzzle). Using the panel data from the Household Income and Labour Dynamics in Australia surveys over the period 2001 to 2005 to perform empirical analyses under the alternative specifications of happiness model, the empirical findings indicate that the peer group income is negatively related to the happiness of individuals. Furthermore, an increase in the peer group income will hurt the poor more than that of rich. Tsui (2014) finds that the impact of income on individual's happiness presents a simple linear relationship. Beja (2014) presents evidence to verify the long-term relationship between income growth and happiness, which is considered as being positive, but very small. This discovery is often considered a refutation of Easterlin Paradox. However, he finds that, in fact, the evidence suggests that the income growth has little effect on long-term increases in happiness.

Empirical evidence often shows that the happiness of the rich is not necessarily higher than that of the poor. Tavor, Gonen, Weber and Spiegel (2018) add the income inequality as a new determinant of happiness to analyze the same issue. They find that the effect of income inequality on happiness is unclear and GDP per capita (income) has no effect on happiness.Kollamparambil (2019) sets South Africa as a sample to discuss the dynamic relationship among happiness, happiness inequality and income. He finds that the income determines the happiness. Lim, Shaw, Liao and Duan (2019) use data from the World Value Survey to assess the impact of income on happiness and examine the moderating effect of social values under East Asia's happiness gap. They find that in Thailand and Philippines, income has the lowest (and not significant) impact on happiness; in Korea and Taiwan, income has the highest (and very significant) impact on happiness. Once the impact of income is adjusted by social values, it becomes insignificant.

Those papers analyzed above have explored the effect of income on happiness. Their findings can be divided into approximately three categories. The first is that the effect of income on happiness is positive; the second is that the effect of income on happiness is negative; the third is that the effect of income on happiness is not significant. In this paper, we do not only focus the linear effect of income on happiness, but also the nonlinear effect of income on happiness. Of course, this is a greatest innovation when compared with that of others' achievements. The hypothesis in this paper gives:

Hypothesis: The effect of income on happiness in China presents an inverted U-shaped curve.

Table 2: Description Statistics of Variables

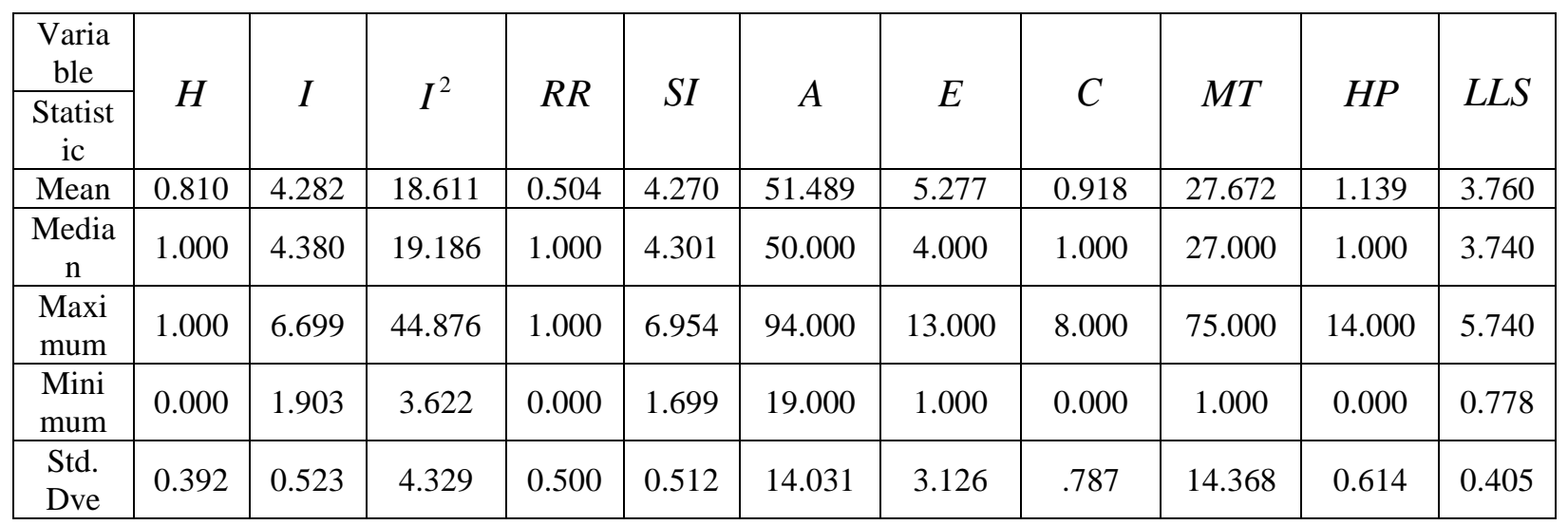

\section{Variable and Model}

\subsection{Variable Description}


The data from the Chinese General Social Survey (CGSS) in 2015 is selected as sample whose size includes 10968 questionnaires. The Chinese General Social Survey Project Survey in 2015 covers 478 villages in 28 provinces/municipalities/autonomous regions in China. In this paper, according to the needs of empirical analysis, we have removed some questionnaires that do not meet the requirements. The number of questionnaires used for empirical analysis is as high as 4371. This data provides a good basis for the comprehensive selection of variables in the econometric model. In this paper, the dependent variable is whether a respondent feels happy or not. If a respondent feels happy, the value will be one. Otherwise, the value will be zero. A respondent's annual income is treated as independent variable. The square of a respondent's annual income is also treated as independent variable. Other variables used in this paper are treated as control variables including registered residence, age, education, children, marriage time, house property and local living standards. Details of these variables are presented in $<$ Table $1>$ in the appendix.

\subsection{Model Specification}

Regarding previous analyses in Section two as a reference, we hypothesize that the effect of income on individual's happiness presents an inverted U-shaped curve. The estimated model used in this paper is presented as follows:

$$
H_{2015}=a_{2015}+\beta_{1} \log I_{2015}+\beta_{2} \log I_{2015}^{2}+\sum_{i=1}^{n} \delta_{i} X_{2015}^{\prime}+\mu_{2015}
$$

Where $a$ represents the constant; 2015 represents the year of 2015; $\beta_{1}$ and $\beta_{2}$ represent the coefficients of each variable. $X^{\prime}$ represents the control variable matrix. $\mu$ represents the white noise. Furthermore, if this hypothesis holds, the coefficients of $\beta_{1}$ and $\beta_{2}$ should be satisfied as follows: $\beta_{1}$ is greater than zero and $\beta_{2}$ is less than zero. More importantly, both should be significant in statistic and nonzero. Because there are a large number of individuals ( $H$ is equal to zero) in the sample, it has the characteristics of zero expansion. If traditional analytical methods such as Logit and Probit are still used, the empirical results may be biased. Based on the research of Loeys, Moerkerke, De Smet and Buysse (2012), the Zero-Inflation-Passion model (Introducing covariates to establish mixed probability distribution for zero and non-zero counts) will be introduced in this paper. In the Zero-Inflation-Passion model, the dependent variable $(H)$ follows the mixed probability distribution.

$$
\left[\begin{array}{l}
P\left(H_{j}=0 \mid X_{j}^{\prime}=\phi\right. \\
P\left(H_{j}=\xi \mid X_{j}^{\prime}\right)=(1-\phi) e^{-\lambda_{j}} \lambda_{j}^{\xi} / \xi !\left(1-e^{-\lambda_{j}}\right)
\end{array}\right.
$$

Where $\xi$ belongs to zero and one; $\lambda_{j}$ is equal to $\exp \left(X_{j}^{\prime} \beta\right) ; \phi$ is greater than zero; $\beta$ is the estimated parameter; $\xi$ is the number of counts; $\phi$ depends on $X^{\prime}$. Then, the maximum likelihood estimation approach will be used to estimate the choice of $H$.

\section{Empirical Analysis}

\subsection{Statistic Description}

The summary statistics of variables used in this paper are presented in <Table 2〉 in the Appendix. $H$ has a mean value of 0.810 with a standard deviation of 0.932 . I has a mean value of 4.282 with a standard deviation of 0.523 . $I^{2}$ has a mean value of 18.611 with a standard deviation of 4.329. $R R$ has a mean value of 0.504 with a standard 
deviation of 0.500. SI has a mean value of 4.270 with a standard deviation of 0.512 . A has a mean value of 51.489 with a standard deviation of 14.031. $E$ has a mean value of 5.277 with a standard deviation of 3.126. $C$ has a mean value of 0.918 with a standard deviation of $0.787 . M T$ has a mean value of 27.672 with a standard deviation of 14.368. $H P$ has a mean value of 1.139 with a standard deviation of $0.614 . L L S$ has a mean value of 3.760 with a standard deviation of 0.405 .

\subsection{Correlation Test}

The correlation matrix between those variables used in this paper is illustrated in <Table 3> in the Appendix. It can be found that the value of most correlation coefficients is relatively small. This applies that in our regression analyses, the multicollinearity is not a material problem [income and happiness $(0.118)$; square of income and happiness ($0.121)$; registered residence and happiness (-0.091); spouse's income and happiness (0.116); age and happiness (0.004); educational level and happiness (0.122); number of children and happiness (-0.028); marriage time and happiness (0.001); house property and happiness (0.077); local living standards and happiness (-0.046)].

\subsection{Results}

The empirical results of Probit and Zero-Inflation-Passion estimations for equation (1) are presented in $\langle$ Table 4$\rangle$ in the Appendix. It can be found that the coefficients of $I$ [0.736 in model (1), 0.646 in model (2), 1.507 in model (4) and 1.420 in model (5)] are positive and significant. Meanwhile, the coefficients of $I^{2}$ [-0.109 in model (1), -0.100 in model (2), -0.214 in model (4) and -0.210 in model (5)] are positive and significant. These results support the hypothesis this paper proposed. In other words, the effect of income on happiness presents an inverted U-shaped curve. Initially, with an increase of income, the individual's happiness will increase. When the happiness reaches a vertex, the individual's happiness will decrease as income increases. This phenomenon is in line with the reality. Moreover, this results are in consistent with the findings of Wang, Pan and Luo (2015). Furthermore, it also can be found that the happiness of an individual who belongs to rural registration is lower than that of an individual who belongs to others. However, the coefficients do not get through the significant test. The coefficients of $S I$ are positive and significant. This means that the happiness of an individual whose spouse has high income is higher than that of an individual whose spouse does not have high income. This result is in keeping with the findings of Rogers and DeBoer (2001). The coefficients of $A$ are negative and significant. This indicates that with the age increasing, the happiness will decrease. This result is in accordance with the findings of Wong, Gong and Fung (2019). The coefficients of $E$ are positive and significant. This means that the happiness of an individual who has a good educational background is greater than that of an individual who does not have a good educational background. This results is the same as the findings of Wang, Cheng and Smyth (2019). The coefficients of $C$ are negative. This means that the happiness of an individual who has children is lower than that of an individual who does not have. Unfortunately, these coefficients do not get through significant test. The coefficients of $M T$ are positive and significant. This means that the happiness of an individual who has a long marriage time is higher that of an individual who has a short marriage time. This result matches the findings of Tao (2018). The coefficients of $H P$ are positive and significant. This means that the happiness of an individual who has more house properties is higher than that of an individual who has less house properties. This result is consistent with the findings of Zheng, Yuan and Zhang (2020). The coefficients of $L L S$ are negative and significant. This means that the happiness of an individual who lives in a higher living standard area is lower than that of an individual who lives in lower living standard area. This result is consistent with the findings of Kenny (1999).

Table 3: Correlation Matrix

\begin{tabular}{|c|c|c|c|c|c|c|c|c|c|c|c|}
\hline $\begin{array}{c}\text { Vari } \\
\text { able }\end{array}$ & $H$ & $I$ & $I^{2}$ & $R R$ & $S I$ & $A$ & $E$ & $C$ & $M T$ & $H P$ & $L L S$ \\
\hline & 1.000 & --- & --- & --- & --- & --- & --- & ---- & ---- & ---- & ---- \\
$H$ & ---- & ---- & ---- & ---- & ---- & ---- & --- & ---- & ---- & ---- & ---- \\
\hline
\end{tabular}




\begin{tabular}{|c|c|c|c|c|c|c|c|c|c|c|c|}
\hline$I$ & $\begin{array}{c}0.118^{* * *} \\
(0.000) \\
\end{array}$ & $\begin{array}{c}1.000 \\
---- \\
\end{array}$ & --- & $\begin{array}{l}---- \\
----\end{array}$ & --- & $\begin{array}{l}---- \\
----\end{array}$ & --- & --- & $\begin{array}{l}---- \\
----\end{array}$ & --- & --- \\
\hline$I^{2}$ & $\begin{array}{c}- \\
0.121^{-} * * \\
(0.000)\end{array}$ & $\begin{array}{c}0.195 * * * \\
(0.000)\end{array}$ & 1.000 & $\begin{array}{l}---- \\
----\end{array}$ & ---- & $\begin{array}{l}--- \\
----\end{array}$ & ---- & $\begin{array}{l}--- \\
----\end{array}$ & $\begin{array}{c}--- \\
----\end{array}$ & ---- & --- \\
\hline$R R$ & $\begin{array}{c}- \\
0.091 * * * \\
(0.000)\end{array}$ & $\begin{array}{l}-0.453 \\
(0.000)\end{array}$ & $\begin{array}{c}- \\
0.452 * * * \\
(0.000)\end{array}$ & $\begin{array}{c}1.000 \\
----\end{array}$ & ---- & $\begin{array}{l}---- \\
----\end{array}$ & ---- & $\begin{array}{l}---- \\
----\end{array}$ & $\begin{array}{l}---- \\
----\end{array}$ & --- & --- \\
\hline SI & $\begin{array}{c}0.116^{* * *} \\
(0.000)\end{array}$ & $\begin{array}{c}0.669 * * * \\
(0.000)\end{array}$ & $\begin{array}{c}0.666 * * * \\
(0.000)\end{array}$ & $\begin{array}{c}- \\
0.414 \\
* * * \\
\\
(0.00 \\
0) \\
\end{array}$ & $\begin{array}{l}1.000 \\
----\end{array}$ & $\begin{array}{l}---- \\
----\end{array}$ & ---- & ---- & ---- & ---- & ---- \\
\hline$A$ & $\begin{array}{l}-0.004 \\
(0.810)\end{array}$ & $\begin{array}{c}-0.240 * * * \\
(0.000)\end{array}$ & $\begin{array}{c}- \\
0.238 * * * \\
(0.000)\end{array}$ & $\begin{array}{c}- \\
0.137 \\
* * * \\
\\
(0.00 \\
0) \\
\end{array}$ & $\begin{array}{c}- \\
0.300 \\
* * * \\
\\
(0.00 \\
0) \\
\end{array}$ & $\begin{array}{c}1.000 \\
----\end{array}$ & ---- & ---- & ---- & ---- & ---- \\
\hline$E$ & $\begin{array}{c}0.122 * * * \\
(0.000)\end{array}$ & $\begin{array}{c}0.552 * * * \\
(0.000)\end{array}$ & $\begin{array}{c}0.564 * * * \\
(0.000)\end{array}$ & $\begin{array}{c}- \\
0.489 \\
* * * \\
\\
(0.00 \\
0) \\
\end{array}$ & $\begin{array}{c}0.488 \\
* * * \\
\\
(0.00 \\
0)\end{array}$ & $\begin{array}{c}- \\
0.303 \\
* * * \\
\\
(0.00 \\
0) \\
\end{array}$ & $\begin{array}{c}1.000 \\
----\end{array}$ & --- & $\begin{array}{l}---- \\
----\end{array}$ & ---- & --- \\
\hline$C$ & $\begin{array}{l}-0.028^{*} \\
(0.060)\end{array}$ & $\begin{array}{c}-0.269^{* * * *} \\
(0.000)\end{array}$ & $\begin{array}{c}- \\
0.262 * * * \\
(0.000)\end{array}$ & $\begin{array}{c}0.198 \\
* * * \\
(0.00 \\
0)\end{array}$ & $\begin{array}{c}- \\
0.278 \\
* * * \\
\\
(0.00 \\
0)\end{array}$ & $\begin{array}{c}0.328 \\
* * * \\
\\
(0.00 \\
0)\end{array}$ & $\begin{array}{c}- \\
0.296 \\
* * * \\
\\
(0.00 \\
0)\end{array}$ & $\begin{array}{c}1.000 \\
----\end{array}$ & $\begin{array}{l}---- \\
----\end{array}$ & $\begin{array}{l}---- \\
----\end{array}$ & --- \\
\hline$M T$ & $\begin{array}{l}0.001 \\
(0.934)\end{array}$ & $\begin{array}{c}-0.312^{* * * *} \\
(0.000)\end{array}$ & $\begin{array}{c}- \\
0.311^{* * *} \\
(0.000)\end{array}$ & $\begin{array}{c}- \\
0.051 \\
* * * \\
\\
(0.00 \\
1)\end{array}$ & $\begin{array}{c}- \\
0.347 \\
* * * \\
\\
(0.00 \\
0)\end{array}$ & $\begin{array}{c}0.160 \\
* * * \\
\\
(0.00 \\
0)\end{array}$ & $\begin{array}{c}- \\
0.387 \\
* * * \\
\\
(0.00 \\
0)\end{array}$ & $\begin{array}{c}0.374 \\
* * * \\
\\
(0.00 \\
0)\end{array}$ & $\begin{array}{c}1.000 \\
----\end{array}$ & ---- & --- \\
\hline$H P$ & $\begin{array}{c}0.077 * * * \\
(0.000)\end{array}$ & $\begin{array}{c}0.105^{* * *} * \\
(0.000)\end{array}$ & $\begin{array}{c}0.118 * * * \\
(0.000)\end{array}$ & $\begin{array}{c}- \\
0.046 \\
* * *\end{array}$ & $\begin{array}{l}0.121 \\
* * * \\
(0.00\end{array}$ & $\begin{array}{c}- \\
0.017 \\
* * *\end{array}$ & $\begin{array}{l}0.092 \\
* * * \\
(0.00\end{array}$ & $\begin{array}{c}0.008 \\
(0.61 \\
3)\end{array}$ & $\begin{array}{c}- \\
0.020 \\
(0.19\end{array}$ & $\begin{array}{c}1.00 \\
0 \\
----\end{array}$ & --- \\
\hline
\end{tabular}




\begin{tabular}{|c|c|c|c|c|c|c|c|c|c|c|c|}
\hline & & & & $\begin{array}{c}(0.00 \\
3)\end{array}$ & 0) & $\begin{array}{c}(0.00 \\
0) \\
\end{array}$ & 0) & & 1) & & \\
\hline$L L S$ & $\begin{array}{c}- \\
0.046^{* * * *} \\
(0.002)\end{array}$ & $\begin{array}{c}0.451 * * * \\
(0.000)\end{array}$ & $\begin{array}{c}0.458 * * * \\
(0.000)\end{array}$ & $\begin{array}{c}- \\
0.342 \\
* * * \\
\\
(0.00 \\
0)\end{array}$ & $\begin{array}{c}0.436 \\
* * * \\
\\
(0.00 \\
0)\end{array}$ & $\begin{array}{c}- \\
0.117 \\
* * * \\
\\
(0.00 \\
0) \\
\end{array}$ & $\begin{array}{c}0.363 \\
* * * \\
\\
(0.00 \\
0)\end{array}$ & $\begin{array}{c}0.181 \\
* * * \\
(0.00 \\
0)\end{array}$ & $\begin{array}{c}- \\
0.173 \\
* * * \\
\\
(0.00 \\
0) \\
\end{array}$ & $\begin{array}{c}0.06 \\
7 * * \\
* \\
\\
(0.0 \\
00) \\
\end{array}$ & $\begin{array}{c}1.00 \\
0 \\
----\end{array}$ \\
\hline
\end{tabular}

Note: * represents $10 \%$ significant level. ** represents 5\% significant level. ***represents $1 \%$ significant level. ( ) represents the standard error.

Table 4: Effect of Income on Happiness

\begin{tabular}{|c|c|c|c|c|c|c|}
\hline \multirow{2}{*}{ Variable } & \multicolumn{3}{|c|}{ Probit Estimation } & \multicolumn{3}{|c|}{ Zero-Inflation-Passion Estimation } \\
\hline & Model (1) & Model (2) & Model (3) & Model (4) & Model (5) & Model (6) \\
\hline$I$ & $\begin{array}{c}0.736 * * * \\
(0.147)\end{array}$ & $\begin{array}{c}0.646^{* * * *} \\
(0.184)\end{array}$ & --- & $\begin{array}{l}1.507 * \\
(0.872)\end{array}$ & $\begin{array}{l}1.420 * \\
(0.817)\end{array}$ & ---- \\
\hline$I^{2}$ & $\begin{array}{l}-0.109 * \\
(0.059) \\
\end{array}$ & $\begin{array}{l}-0.100 * \\
(0.060) \\
\end{array}$ & --- & $\begin{array}{l}-0.214 * \\
(0.113)\end{array}$ & $\begin{array}{c}-0.210^{* *} \\
(0.105) \\
\end{array}$ & --- \\
\hline$R R$ & $\begin{array}{l}-0.007 \\
(0.058) \\
\end{array}$ & $\begin{array}{l}-0.007 \\
(0.059) \\
\end{array}$ & $\begin{array}{l}-0.020 \\
(0.058) \\
\end{array}$ & $\begin{array}{r}0.035 \\
(0.082) \\
\end{array}$ & $\begin{array}{l}-0.010 \\
(0.090)\end{array}$ & $\begin{array}{r}-0.038 \\
(0.086) \\
\end{array}$ \\
\hline SI & $\begin{array}{c}0.179 * * * \\
(0.003) \\
\end{array}$ & $\begin{array}{l}0.184 * * \\
(0.062)\end{array}$ & $\begin{array}{c}0.250 * * * \\
(0.055) \\
\end{array}$ & $\begin{array}{l}0.246^{*} \\
(0.090)\end{array}$ & $\begin{array}{c}0.255^{* * *} \\
(0.095) \\
\end{array}$ & $\begin{array}{c}0.347 * * * \\
(0.087) \\
\end{array}$ \\
\hline$A$ & $\begin{array}{c}-0.013 * * \\
(0.006) \\
\end{array}$ & $\begin{array}{c}-0.012 * * \\
(0.006) \\
\end{array}$ & $\begin{array}{l}-0.010^{*} \\
(0.006)\end{array}$ & $\begin{array}{c}-0.016^{* *} \\
(0.009)\end{array}$ & $\begin{array}{l}-0.015 * \\
(0.009) \\
\end{array}$ & $\begin{array}{l}-0.012 \\
(0.008)\end{array}$ \\
\hline$E$ & $\begin{array}{c}0.050 * * * \\
(0.000) \\
\end{array}$ & $\begin{array}{c}0.051 * * * \\
(0.011) \\
\end{array}$ & $\begin{array}{c}0.059^{* * * *} \\
(0.010) \\
\end{array}$ & $\begin{array}{c}0.076 * * * \\
(0.023) \\
\end{array}$ & $\begin{array}{c}0.079 * * * \\
(0.020) \\
\end{array}$ & $\begin{array}{c}0.089 * * * \\
(0.020) \\
\end{array}$ \\
\hline C & $\begin{array}{l}-0.003 \\
(0.031) \\
\end{array}$ & $\begin{array}{l}-0.008 \\
(0.031)\end{array}$ & $\begin{array}{l}-0.006 \\
(0.031)\end{array}$ & $\begin{array}{l}-0.002 \\
(0.042)\end{array}$ & $\begin{array}{l}-0.004 \\
(0.046) \\
\end{array}$ & $\begin{array}{l}-0.010 \\
(0.044)\end{array}$ \\
\hline$M T$ & $\begin{array}{c}0.020^{* * *} \\
(0.006) \\
\end{array}$ & $\begin{array}{c}0.019 * * * \\
(0.006) \\
\end{array}$ & $\begin{array}{c}0.018 * * * \\
(0.006) \\
\end{array}$ & $\begin{array}{c}0.027 * * * \\
(0.002) \\
\end{array}$ & $\begin{array}{c}0.026 * * * \\
(0.009) \\
\end{array}$ & $\begin{array}{c}0.022 * * * \\
(0.008) \\
\end{array}$ \\
\hline$H P$ & --- & $0.134 * * *$ & $0.140 * * *$ & --- & $0.597 * * *$ & $0.564 * * *$ \\
\hline
\end{tabular}




\begin{tabular}{|c|c|c|c|c|c|c|}
\hline & ---- & $(0.036)$ & $(0.036)$ & ---- & $(0.117)$ & $(0.116)$ \\
\hline$L L S$ & --- & $\begin{array}{l}-0.121 * \\
(0.063)\end{array}$ & $\begin{array}{c}-0.185^{* * * *} \\
(0.062) \\
\end{array}$ & ---- & $\begin{array}{l}-0.163^{*} \\
(0.100)\end{array}$ & $\begin{array}{l}-0.112 * \\
(0.067)\end{array}$ \\
\hline Const & $\begin{array}{c}1.104 \\
(1.014)\end{array}$ & $\begin{array}{c}1.124 \\
(1.020)\end{array}$ & $\begin{array}{l}-0.256 \\
(0.347)\end{array}$ & $\begin{array}{l}-2.265 \\
(1.629)\end{array}$ & $\begin{array}{l}-1.954 \\
(1.656)\end{array}$ & $\begin{array}{l}0.883 * \\
(0.551)\end{array}$ \\
\hline $\begin{array}{c}\text { McFadde } \\
\text { n } R^{2}\end{array}$ & 0.028 & 0.032 & 0.030 & ---- & ---- & ---- \\
\hline $\begin{array}{c}\text { LR } \\
\text { Statistic }\end{array}$ & 119.693 & 137.319 & 128.423 & ---- & ---- & ---- \\
\hline P-value & 0.000 & 0.000 & 0.000 & ---- & --- & ---- \\
\hline $\begin{array}{l}\text { Wald } \\
\text { chi2 }\end{array}$ & ---- & ---- & ---- & 22.780 & 51.890 & 48.990 \\
\hline P-value & --- & --- & --- & 0.004 & 0.000 & 0.000 \\
\hline $\begin{array}{l}\text { Inflate_c } \\
\text { ons }\end{array}$ & $\begin{array}{l}---- \\
---- \\
\end{array}$ & $\begin{array}{l}---- \\
---- \\
\end{array}$ & $\begin{array}{l}---- \\
---- \\
\end{array}$ & $\begin{array}{c}1.519 * * * \\
(0.232) \\
\end{array}$ & $\begin{array}{c}1.409 * * * \\
(0.101) \\
\end{array}$ & $\begin{array}{c}1.442 * * * \\
(0.116) \\
\end{array}$ \\
\hline $\begin{array}{c}\text { Observat } \\
\text { ion }\end{array}$ & 4371 & 4371 & 4371 & 4371 & 4371 & 4371 \\
\hline
\end{tabular}

Note: * represents $10 \%$ significant level. ** represents 5\% significant level. ***represents $1 \%$ significant level. ( ) represents the standard error.

Table 5: Robustness Test

\begin{tabular}{|c|c|c|c|}
\hline \multirow{3}{*}{ Variable } & \multicolumn{3}{|c|}{ Probit Estimation } \\
\cline { 2 - 4 } & $\begin{array}{c}\text { Sub-sample One } \\
\text { (Eastern Region) }\end{array}$ & $\begin{array}{c}\text { Sub-sample Two } \\
\text { (Central Region) }\end{array}$ & $\begin{array}{c}\text { Sub-sample Three } \\
\text { (Western Region) }\end{array}$ \\
\hline \multirow{2}{*}{$I$} & $0.670^{* * *}$ & $1.791^{* *}$ & $1.110^{* * *}$ \\
& $(0.147)$ & $(0.867)$ & $(0.145)$ \\
\hline \multirow{2}{*}{$I^{2}$} & $-0.055^{* * *}$ & $-0.229^{* *}$ & $-0.142^{*}$ \\
& $(0.012)$ & $(0.110)$ & $(0.073)$ \\
\hline \multirow{2}{*}{$R R$} & -0.076 & -0.076 & -0.013 \\
& $(0.116)$ & $(0.108)$ & $(0.086)$ \\
\hline \multirow{2}{*}{$S I$} & $0.159^{* * *}$ & $0.251^{* *}$ & $0.226^{* *}$ \\
& $(0.038)$ & $(0.110)$ & $0.092)$ \\
\hline \multirow{2}{*}{$A$} & $-0.030^{* * *}$ & $-0.006^{* * *}$ & $-0.006^{* *}$ \\
& $(0.011)$ & $(0.001)$ & $0.003)$ \\
\hline \multirow{2}{*}{$E$} & $0.050^{* * *}$ & $0.045^{* *}$ & $0.069^{* * *}$ \\
& $(0.018)$ & $(0.021)$ & $-0.017)$ \\
\hline \multirow{2}{*}{$C$} & -0.004 & -0.0002 & $(0.021$ \\
& $(0.065)$ & $(0.055)$ & $0.046)$ \\
\hline \multirow{2}{*}{$M T$} & $0.036^{* * *}$ & $0.031^{* * *}$ & $(0.009)$ \\
\hline
\end{tabular}




\begin{tabular}{|c|c|c|c|}
\hline$H P$ & $\begin{array}{c}0.308^{* * *} \\
(0.081)\end{array}$ & $\begin{array}{c}0.232^{* * *} \\
(0.088)\end{array}$ & $\begin{array}{c}0.212^{* * *} \\
(0.071)\end{array}$ \\
\hline LLS & $-0.223^{* *}$ & $\begin{array}{c}-0.286^{* *} \\
(0.111)\end{array}$ & $(0.116)$ \\
\hline Const & -0.742 & $3.645^{*}$ & 1.715 \\
$(1.875)$ & $(1.590)$ \\
\hline $\begin{array}{c}\text { McFadde } \\
\mathrm{n} R^{2}\end{array}$ & 0.038 & 0.035 & 0.035 \\
\hline $\begin{array}{c}\text { LR } \\
\text { Statistic }\end{array}$ & 49.047 & 45.344 & 66.362 \\
\hline P-value & 0.000 & 0.000 & 0.000 \\
\hline $\begin{array}{c}\text { Observat } \\
\text { ion }\end{array}$ & 1530 & 1093 & 1748 \\
\hline
\end{tabular}

Note: * represents $10 \%$ significant level. ** represents 5\% significant level. ***represents $1 \%$ significant level. ( ) represents the standard error.

\subsection{Robustness Test}

Happiness refers to a person's psychological mood of being satisfied with his or her self-worth and hoping to keep the status quo. However, life around us is changing all the time. So there are also many factors that affect our happiness. Quantitative and qualitative analysis of the impact of other factors on happiness has also become very difficult. Although the model and statistical analysis have been used to analyze the impact of those factors on happiness, the stability of these empirical results is still questionable. Therefore, we need to further test the stability of those empirical results. Because the sample used in this paper basically cover the whole of China, we divide the sample into three subsamples (eastern region, central region and western region) to re-estimate the results in $\langle$ Table 4$\rangle$. The re-estimated results are presented in $\langle$ Table 5 $\rangle$ in the Appendix.

As the re-estimated results in $\langle$ Table 5> indicates, Most of the features in $\langle$ Table 5> are the same as those in $\langle$ Table $4>$ except for the magnitude of coefficients and the significance of coefficients. To this end, we can confirm that the estimated results in $\langle$ Table 4$\rangle$ are valid and robust.

\section{Conclusion}

This paper sets China as an example to explore the effect of income on happiness with the data from the Chinese General Social Survey in 2015. Then, both Probit model and Zero-Inflation-Passion model are employed to conduct empirical analyses. The empirical results support the hypothesis (the effect of income on happiness presents an inverted U-shaped curve) this proposed. This means that with an increase of income, the individual's happiness will increase. When the happiness reaches a vertex, the individual's happiness will decrease as income increases. Moreover, spouse's income, educational level, marriage time and house property have a positive and significant effect on happiness.Conversely, age and local living standards have a negative and significant effect on happiness. Unfortunately, even though registered residence and children have a negative effect on happiness, they do not get through the significant test. To ensure the reliability and accuracy of the above empirical results, The full sample which cover the whole of China is divided into three sub-samples (eastern region, central region and western region) to re-estimate the the effect of income on happiness, respectively. Each sub-sample empirical results verify that the results this paper provided are quite robust.

Based on the evidences this paper provided, individual can take corresponding measures to increase his or her happiness. For example, individual can increase his or her happiness via increasing his or her educational background. Meanwhile, individual can also increase his or her happiness through escaping the high standard living area. More importantly, due to the effect of income on happiness presents an Inverted curve, a person who is located in the left hand of inverted U-shaped curve can increase his or her happiness by increasing his or her income. Conversely, a 
person who is located in the right hand of inverted U-shaped curve can increase his or her happiness by increasing his or her entertainment time or others, but not increasing his or her income. Furthermore, because happiness is immeasurable and incalculable, it is difficult to put it into an economic model to explore the impact of income on happiness. this point leaves a room for the upcoming scholars to study this proposition. Of course, this paper enriches the current literature on this topic with sample from China.

\section{References}

Ball, R., \& Chernova, K. (2008). Absolute income, relative income, and happiness. Social Indicators Research, 88(3), 497-529.

Bartram, D. (2011). Economic migration and happiness: Comparing immigrants' and natives' happiness gains from income. Social Indicators Research, 103(1), 57-76.

Becchetti, L., Trovato, G., \& Londono Bedoya, D. A. (2011). Income, relational goods and happiness. Applied Economics, 43(3), 273-290.

Beja, E. L. (2014). Income growth and happiness: Reassessment of the Easterlin Paradox. International Review of Economics, 61(4), 329-346.

Binswanger, M. (2006). Why does income growth fail to make us happier?: Searching for the treadmills behind the paradox of happiness. The Journal of Socio-Economics, 35(2), 366-381.

Bruni, L., \& Stanca, L. (2006). Income aspirations, television and happiness: Evidence from the world values survey. Kyklos, 59(2), 209-225

Caporale, G. M., Georgellis, Y., Tsitsianis, N., \& Yin, Y. P. (2009). Income and happiness across Europe: Do reference values matter?. Journal of Economic Psychology, 30(1), 42-51.

Kenny, C. (1999). Does growth cause happiness, or does happiness cause growth?. Kyklos, 52(1), 3-25

Knabe, A., \& Rätzel, S. (2010). Income, happiness, and the disutility of labour. Economics Letters, 107(1), 77-79.

Kollamparambil, U. (2019). Happiness, Happiness Inequality and Income Dynamics in South Africa. Journal of Happiness Studies, 1-22.

Lim, H. E., Shaw, D., Liao, P. S., \& Duan, H. (2019). The Effects of Income on Happiness in East and South Asia: Societal Values Matter?. Journal of Happiness Studies, 4, 1-25.

Loeys, T., Moerkerke, B., De Smet, O., \& Buysse, A. (2012). The analysis of zero-inflated count data: Beyond zeroinflated Poisson regression. British Journal of Mathematical and Statistical Psychology, 65(1), 163-180.

Oshio, T., Nozaki, K., \& Kobayashi, M. (2011). Relative income and happiness in Asia: Evidence from nationwide surveys in China, Japan, and Korea. Social Indicators Research, 104(3), 351-367.

Paul, S., \& Guilbert, D. (2013). Income-happiness paradox in Australia: Testing the theories of adaptation and social comparison. Economic Modelling, 30, 900-910.

Powdthavee, N. (2010). How much does money really matter? Estimating the causal effects of income on happiness. Empirical economics, 39(1), 77-92.

Rogers, S. J., \& DeBoer, D. D. (2001). Changes in wives' income: Effects on marital happiness, psychological wellbeing, and the risk of divorce. Journal of Marriage and Family, 63(2), 458-472.

Stutzer, A. (2004). The role of income aspirations in individual happiness. Journal of Economic Behavior \& Organization, 54(1), 89-109.

Tao, H. L. (2018). Marriage and Happiness: Evidence from Taiwan. Journal of Happiness Studies, 2, 1-19.

Tavor, T., Gonen, L. D., Weber, M., \& Spiegel, U. (2018). The effects of income levels and income inequalities on happiness. Journal of Happiness Studies, 19(7), 2115-2137.

Tsui, H. C. (2014). What affects happiness: Absolute income, relative income or expected income?. Journal of Policy Modeling, 36(6), 994-1007.

Wang, H., Cheng, Z., \& Smyth, R. (2019). Wealth, Happiness and Happiness Inequality in China. In Wealth (s) and Subjective Well-Being (pp. 445-461). Springer, Cham.

Wang, P., Pan, J., \& Luo, Z. (2015). The impact of income inequality on individual happiness: Evidence from China. Social Indicators Research, 121(2), 413-435.

Wong, N., Gong, X., \& Fung, H. H. (2019). Does valuing happiness enhance subjective well-being? The agedifferential effect of interdependence. Journal of Happiness Studies, 3, 1-14.

Zheng, X., Yuan, Z. Q., \& Zhang, X. (2020). Does happiness dwell in an owner-occupied house? Homeownership and subjective well-being in urban China. Cities, 96, 102404. 